\title{
UCLA
}

InterActions: UCLA Journal of Education and Information Studies

Title

Revolutionary Critical Pedagogy

Permalink

https://escholarship.org/uc/item/7qj2b570

Journal

InterActions: UCLA Journal of Education and Information Studies, 6(2)

ISSN

1548-3320

Author

McLaren, Peter

Publication Date

2010-05-27

DOI

10.5070/D462000683

Peer reviewed 


\section{Revolutionary Critical Pedagogy}

Since the mid-1990s, the focus of my work has shifted discernibly, if not dramatically, from a preoccupation with poststructuralist analyses of popular culture, in which I attempted to deploy contrapuntally critical pedagogy, neoMarxist critique and cultural analysis, to a revolutionary Marxist humanist perspective. My focus shifted away from the politics of representation and its affiliative liaison with identity production and turned towards the role of finance capital and the social relations of production. Against a utopian theory of entrepreneurial individuality and agency backed by a voluntarism unburdened by history, I came to see the necessity of transforming the very structures of white supremacist capitalist patriarchy by means of a pedagogical praxis guided by the revolutionary knowledges of historical materialism. In so doing, questions of patriarchal and sexist ideology are connected to their material origins-of social labor - that emphasize the relations between the sexes and how the distribution of labor in capitalist economies have generated the alienating conditions in which men and women relate to themselves and to one another (Ebert \& Zavarzadeh, 2008).

I locate my work within what I take to be the fundamental condition of late modernity - a brutal and systematic extraction of surplus value from proletarianized regions of the world (usually decaying in a climate of bourgeoiscomprador nationalism) culminating in a condition of substantive inequality and an egregiously unequal division of labor - a condition that is structurally inescapable under the regime of capital. Through the generalization of exchangevalues mediated by the machinations of capital accumulation on a global scale, this regressive situation has spawned alienated lifeworlds festering in the swamp of reification and the commodification of everyday life. Since my shift in focus, I have come to view the assertion of many poststructuralists-that Marxism constitutes a totalizing pressuring of meaning into semiotic foreclosure, placing an overlay of determinism on the free interplay of cultural discourses with their free-floating auto-intelligibilities, their aleatory and indeterminable play of the sign, and turning the jazz of signification into a military march of pre-ordained procrustean meanings - as an exclusion of causality from the domain of history by replacing it with difference and play. In effect, by situating the social as a contingent totality, the avant-garde politics of representation articulated by the poststructuralists become part of a larger ensemble of textual reading practices that obscure the production practices of capitalism (Ebert \& Zavarzadeh, 2008).

I also had serious problems with what progressive educators were describing as the struggle for democracy in the public sphere because so much of this discourse involved pedagogically fostering a respect for the values of democratic citizenship and appealing to moral sentiments and critical reasoning. 
Of course, this is bound to fail because it rests on an appeal to the individual's consciousness - a move that does little to parry the most devastating effects of capital and is ineffective in bringing about capital's inanation. As Istvan Meszaros (2008) notes, an appeal to individual consciousness ultimately remains insufficient because "it avoids the social causes of the denounced negative symptoms" (p. 341). He adds that "what is absolutely excluded is the possibility of changing the structural determinations of the established social order that produce and reproduce the destructive effects and consequences" (p. 341). I take the position that the worker is the producing subject of capitalist society and the capitalist is the pseudo-subject. As Meszaros explains:

Notwithstanding the fetishistic mystifications of the capital system, the real producing subject is the worker; the capitalist as the presumed controlling subject -who is in fact firmly controlled through the necessarily prevailing structural imperatives of the established order-can only be a usurping pseudo subject. Consequently, only the actually producing subject, labor, can acquire the feasible and productively viable regulatory consciousness under the historical conditions of our time. (p. 346)

It is the social relations of labor that determines a person's class location, not the opportunities for engorging in consumptive practices. Those who have to sell their labor power to earn a living (i.e., those who produce the profit for the capitalist) are part of one class. Those who purchase human labor and take the profit away from labor are part of another class (Ebert and Zavarzadeh, 2008). Subsequently, the market is distributing the already available wealth. While, for instance, the stock market may seem to produce wealth, it is really just redistributing the wealth produced by the labor of the workers. Profit does not come from market relations (buying low and selling high), but from human labor power. In this, I follow Marx's focus on the development of human productive forces - a very complex process that is historically related to the material conditions of production and the class struggle. The profound incompatibility between the forces and relations of production produces tremendous social conflict. John Bellamy Foster (1996) vividly captures this dilemma in the following description:

Every given stage of development of the productive forces of society - that is, of the human species, and of the division of labor-is bound up historically with certain social relations of production, particularly class relations. Once a particular form of class domination comes into existence as a result of this complex process of historical development, the dominant element in the relations attempts to freeze it into place, and the existing society loses its progressive character. Despite changes in the material conditions of production, any ruling class will seek to preserve its rule at all cost, thus becoming a fetter on further 
social and economic development. The state, law, religion, and the entire realm of ideas, to the extent that they represent the overarching interests in society and are conditioned by the underlying set of socioeconomic relations, will all be enlisted for the purpose of defending the status quo and of patching up society's contradictions. (p. 21)

In the field of education, Marxism's protean focus on proletarian selfactivity and the self-organization of the popular majorities are anathema to much of the work that falls under the dubious classification of social justice education. Although well meaning progressive educators might be willing to criticize the manner in which humans are turned into dead objects (i.e., what Marxists refer to as fetishized commodities), they are often loathe to consider the fact that within capitalist society, all value originates in the sphere of production and a main role of schools is to serve as agents or functionaries of capital. Furthermore, these educators fail to understand that education is more reproductive of an exploitative social order than a constitutive challenge to it precisely because it rests on the foundations of capitalist exchange value. What is necessary, as Glenn Rikowski (2007) argues, is for the inequalities of labor-power quality generated within the capitalist labor process to undergo re-equalization to the socially average level in order to attain the equalization of labor-power values that are the foundation of social justice in capitalism.

The unmeasured condemnation and broadside assaults on Marx by the academy in general and education in particular treats Marxism as a chthonic adventure, akin to what Valerie Scatamburlo-D'Annibale (2009) refers to as "a form of ideological Neanderthalism, an antediluvian memory invoked by those trapped in the mental furniture of a bygone era" (p. 23). The soi-dissant scholars who would so vigorously dismiss Marxist theory appear to me to be cut from the same cloth as those knowledge producers whom E. P. Thompson called "the bourgeois lumpen-intelligensia aspirant intellectuals, whose amateurish intellectual preparation disarms them before manifest absurdities and elementary philosophical blunders... while many of them would like to be 'revolutionaries', they are themselves the products of a particular 'conjuncture' which has broken the circuits between intellectuality and practical experience... and hence they are able to perform imaginary revolutionary psycho-dramas (in which each outbids the other in adopting ferocious verbal postures) while falling back upon a very old tradition of bourgeois elitism" (as cited in Scatamburlo-D'Annibale, 2009, p. 27). Their retrograde, opportunistic, and banalizing politics situates itself as a culture of liberal compassion and a polyglot cosmopolitanism that effectively masquerades an unwillingness to comprehend neocolonialism and to ignore the contradictions inherent in the system of commodity production and its manifold mediations of our concrete quotidian existence. Further, it signifies a refusal to consider uneven and combined development, a structured silence and motivated 
amnesia surrounding the urgent task of historicizing power relations in concrete material conditions of production and reproduction. There exists a grand denial of responsibility to disclaim the limitations of bourgeois ethics in the project of social transformation and a studied reluctance to engage the concrete multilayered totality of everyday life (read as a determinate socio-historical process) in which use value is subordinated to exchange value (see San Juan, 2002).

I hold to the position that intellectual production occurs in interaction with material production. This relationship is neither mechanical nor deterministic. As Ernst Fischer (1996) explains:

Intellectual production does not follow material production but occurs simultaneously and in constant interaction with it. What emerges as the "superstructure" is a totality of prescriptions and prohibitions, laws, institutions, judgements, and prejudices which corresponds to the economic structure of society, the degree of division of labor and the interests of the class which, by reason of the division of labor, has become the ruling class at that time. Hence the ideas of the rulers are the dominant ideas, but not the only ones, of the epoch. Marx stressed again and again that every new society carries its own negation within itself the inner contradiction which finds its most striking expression in the class struggle. Every new society is therefore the negation of the preceding one, whose habits, ideas and notions continue to exist deep within it...And at the same time the future society ripens as a negation inside the existing one, conditioned by the growth of the material and spiritual forces of production. Thus the dominant ideas are always permeated by other, rebellious ones, which may be forward- or backward-looking, so that the class struggle is fought not only as an economic but also as a political and intellectual battle. (p. 97)

Human decisions are always conditioned and human history is not unconditional - praxis is a world-changing activity since we are able to change the circumstances in which we find ourselves intractably enmeshed. Production relations maintain what has already been achieved whereas material and intellectual productive forces push society forward.

Local and transnational movements for social justice have been significantly impacted by what has been taking place on a global basis since capital began responding to the 1970s crisis of Fordist-Keynesian capitalismwhich William I. Robinson (2008) has characterized as capital's ferocious quest to break free of nation-state constraints to accumulation and $20^{\text {th }}$ century regulated capital-labor relations based on a limited number of reciprocal commitments and rights. In the time since, we have been witnessing the profound dismantling of national economies. They are being reorganized and reconstituted as component elements or segments of a larger global production and financial system that is organized in a globally fragmented and decentralized way, and is controlled by the concentrated and centralized power of the transnational capitalist class 
(Robinson, 2008). While there still exists national capital, global capital, and regional capital, the hegemonic fraction of capital on a world scale is now transnational capital.

New mechanisms of accumulation have spurred the development of a model in which transnational fractions of capital have become dominant. They include a cheapening of labor and the growth of flexible, deregulated and deunionized labor where women always experience super-exploitation in relation to men; the dramatic expansion of finance capital; the creation of a global and regulatory structure to facilitate the emerging global circuits of accumulation; and neoliberal structural adjustment programs which seek to create the conditions for frictionless operations of emerging transnational capital across borders and between countries. The role of the nation-state has changed to meet globally uniform laws that protect capital against the interests of the international working class. The nation-state still serves local capital, but it can no longer fetter the transnational movement of capital with its endless chains of accumulation.

The cultural turn in much of current postmodern and postcolonial criticism is not a passing trend but rather a structural feature of capitalism. Particularly during times of crisis, capitalism turns to culture to solve the contradictions that it cannot resolve in its actual material practices (Ebert \& Zavardadeh, 2008). Through the medium of experience, the individual is mistaken as the source of social practices and this process of misidentification becomes a capitalist archestrategy that marginalizes collectivity and protects the individual as the foundation of entrepreneurial capitalism. Consequently, the well-being of the collectivity is replaced by a "politics of consumption" that champions the singularities of individuals by ennobling the desire to obtain and consume objects of pleasure. Experience in this view becomes non-theoretical and beyond the real of history. This is precisely why we need to locate all human experience in a world-historical frame; that is, within specific social relations of production.

The overall agenda I have been trying to develop since the mid-1990s is captured in the description of what Meszaros (2008) calls socialist education: "the social organ through which the mutually beneficial reciprocity between the individuals and their society becomes real" (p. 347). My concern has been with marshaling critical pedagogy as a broad, non-sectarian coalition or social movement into the service of altering historical modes of production and reproduction in specific social formations, including if not especially educational formations. Critical revolutionary pedagogy, as I have been trying to develop it, attempts to create the conditions of pedagogical possibility that enables students to see how, through the exercise of power, the dominant structures of class rule protect their practices from being publicly scrutinized as they appropriate resources to serve the interests of the few at the expense of the many (Ebert \& Zavarzadeh, 2008). 
There is, for lack of better terms, left-liberal critical pedagogy, liberal critical pedagogy, conservative critical pedagogy, and variants of each of these. In opposition to these there is revolutionary critical pedagogy, which myself and others have been trying to develop. These are very rough terms and certainly need to be refined, but I do not have the space to do this here. Each of these approaches to pedagogy has implicit or explicit views of the state. Critical pedagogy in the United States is overwhelmingly liberal, and converges, unintentionally in most instances, with neoliberal ideology, policy, and practice. In general, it views the state as the "social state" (here I shall borrow some terms from Tony Smith) where symbolic and moral philosophy is the systematic expression of the normative principles of the Keynesian welfare state. In other words, it is a version of the state that offers wage labor as the normative principles of modern society. Some conservative and even liberal-centrist educators take a neoliberal state as the norm, which we could also call the entrepreneurial state-in which generalized commodity production requires a world market and adheres to Hayek's principle that capital's law of value in the abstract must be followed. Some left-liberal educators look to create a new model of the state which could be called an "activist state" (again, borrowing these terms from Tony Smith) that is based, in large part, on the work of Polyani, and includes methods of aggressive state intervention into its industrial policy. International capital still predominates in this model and there will be an inevitable government and global trade dependence on it. Of course, those who govern the activist state desire to place government restrictions on the rules and regulations for attracting global investment capital. Hence there is a concerted attempt to lessen the worst and most exploitative aspects of the state. There are also some left-liberal educators who prefer the concept "cosmopolitan state." This model is largely derived from the work of Habermas, where forms of global market governance can prevail that is intra-national rather than national; here there is a focus on the development of a global civil society.

I do not ascribe to any of the models. I believe it is impossible to manage democratically wage labor on a global scale by placing severe restrictions on global financial and derivative markets. For example, how would the cosmopolitan state help the 172 IMPA (Industrias Metalúrgicas y Plásticas Argentina) workers who make aluminum products, such as cans, foils, and wrappers? What about the question of property ownership of the mass means of production? There would be a stress on greater democratic control of the economy by those who lack access to capital, but it would still support wage labor-and Marx has shown us that wage labor only "appears" to include an equal exchange. Workers sell their capacity to labor to an employer who is able to extract a higher value from the worker than the workers' means of surviving. How could a global state founded upon wage labor work? It is, in my mind, impossible to build a 
socialist state based on nationalized property because, as Peter Hudis has pointed out, capital can exist as a social form of mediation even in the absence of private ownership.

Of course, there are other models, such as market socialist models. Some of them incorporate a commodity market within a system of democratically selfmanaged and worker-run industries. I do not denigrate these more progressive models; some of them have good ideas and are much better than the neoliberal state model that now has international reach. However, let me break the situation down into two basic and competing visions of globalization. The first version is what we could call civil societarian. If we believe that we have witnessed a qualitative transformation of capitalism, beginning in the post-World War II era, a transformation that is grounded in information-based technology and automation, that has basically marginalized manufacturing and productive capital; if we believe that finance capital flows effortlessly across national boundaries; if we believe that we have an information or knowledge economy of immaterial labor where productive capital and the working classes are becoming increasingly irrelevant to social transformation; and if we believe that the nation-state is powerless, then we would probably ascribe to some kind of civil societarianismputting faith in civil society, in NGOs and in the new social movements-because we probably believe that civil society or the public sphere is at least partially autonomous from the state and the market. But such a position ultimately facilitates the privatization of former state-run services and represents a turn from the global to the local for public funding of social service projects, as John Holst and others have argued.

I take the position that we have not arrived at the end of the nation-state (although we should de-reify the nation-state and not assume a nation-statecentric position), but that the world has been divided into the global proletariat and working class, and the working-class and the peasantry are at the forefront of anti-neoliberalism struggles. This view maintains that the fundamental contradictions of our time are not external relations such as the local versus the global, but contradictory relations internal to the process of capitalism itself, contradictions that manifest themselves through the long history of vertical and horizontal expansions of capitalism. Instead of ascribing to the civil societarian position which utilizes a limited reproductive praxis (where one merely tries to better one's position as an individual or a group within a dialectical relation) I ascribe to a critical revolutionary praxis where one understands the internal relations of capital and struggles to overcome them, to transcend them by means of creating a world where value production ceases to exist. But the question we need to ask is: How do we abolish value production, wage labor?

We need to go beyond state intervention into the economy, since this is not socialism. State intervention into the economy does not prevent value-producing 
labor, alienated labor. In fact, capital is a social relation of abstract labor, and it is precisely capital as a social relation that must be transcended. This is the challenge for all of us. To go up against the ideological state apparatuses (that also have coercive practices such as non-promotion and systems of privilege for those who follow the rules) and the repressive state apparatuses (that are also coercive in that they secure internal unity and social authority ideologically via patriotism and nationalism) is not an easy task. There are disjunctions and disarticulations within and between different social spaces of the superstructure and we must work within those, in spaces of the legal and ideological systems that can be transformed in the interests of social and economic justice. The struggle is multi-pronged.

Let me clarify that I do not think the civil societarian position is useless. It can do much good. I also do not think we should juxtapose the civil societarian position against the critical revolutionary position. We should take a dialectical approach. Dialectics is not about juxtaposition or "either-or," but about mediation or "both-and." We can use them both, but my main point is that we need to be guided by a larger social vision that does not assume the state and civil society are autonomous. Civil society is part and parcel of state apparatuses. We fool ourselves if we think there is a strong autonomy in civil society. The larger vision takes into consideration the social totality, the way capitalism has permeated all spheres of social life, including civil society or the public sphere. This mandates that we need to create a social universe outside of capital's value form. Anything short of this will not bring about emancipation. Revolutionary critical pedagogy strives for the abolition of capital as a social relation. This is the major difference between my position and that of many other critical educators.

\section{Pedagogy of Critique Against a Pedagogy of Desire}

The pedagogy of desire is grounded in Weberian theories of class as lifestyle and consumption, augmented by a poststructuralist perspective on the libidinal economy and how it impacts the impossibility of political agency. Within this context, a pedagogy of desire is about the thrill of corporeal pleasure; it mirrors the conditions of alienated capitalism, because, in reality, the pedagogy of desire is about teaching adjustment to existing social relations in the guise of a radical politics. It is about the transference of a teacher's desire to smash the norms of everyday life, about the emotional thrill of going against the grain of the social order-of being a hellion of the seminar room-and not about a commitment to build a more just society through political organizing and community participation, that is, through working strategically outside of the hegemonic state apparatus but tactically inside. A pedagogy of desire is isolated from the social contradictions and historical contradictions that determine their 
relations. Within a pedagogy of desire, arguments, modes of inquiry and concepts are irrelevant. What matters most is how the teachers and students feel-not what they think or do, but how they feel (Ebert, 2009). A pedagogy of desire considers itself a "post" class pedagogy based on lifestyle, and irony, in which the ruling class avoids confronting the reality of others whose misery is the condition of their prosperity. A pedagogy of desire does not emancipate students from economic oppression but is designed to free teachers and students from emotional distress. The purpose of pedagogies of desire is not understanding but seduction and emotional investment in teaching as an affirmation of power. Pedagogies of desire are those developed by teachers whose fundamental needs have already been met (Ebert \& Zavarzadeh, 2008). It is the pedagogy of an isolated, alienated, bourgeois subject. It is a pedagogy of free expression. It enforces anti-intellectual and trans-social individualism. A pedagogy of desire sees oppression as a question of identity - the experience of being black, gay, but oppression cannot be explained by experience. We need an analysis of experience, of experience effects, an analysis that, in other words, goes beyond experience. You only learn from experiences that you learn from, and this requires a language to interpret experience, a language that can help us unpack the material conditions of experiences. A pedagogy of desire takes the position that one can only learn what one already knows. This needs to be contrasted with a pedagogy of critique.

A pedagogy of critique is aimed at freedom from necessity. Teresa Ebert (2009) writes that a pedagogy of critique is a materialist critique whose purpose is not simply to perform an immanent examination of the cognitive validity of categories and forms of knowledge (by locating contradictions in the rules and systems necessary to the production of those forms) but to relate these categories to the outside, material conditions of their possibility. The role of materialist critique is to begin with an immanent investigation of a system or a practice in its own terms and to relate these inside terms to their outside historical and social conditions. Materialism, as I am using the term, consists of the objective productive activities of humans that involve them in social relations under definite historical conditions that are independent of their will and are shaped by struggle between contesting classes over the surplus produced by social labor. Derrida argues that critique has no ground because there is no outside, only the economy of signification, the inside and outside of language effects-outcomes of representations. The very language, for instance, with which we articulate or describe totalizations deconstructs those totalizations, according to Derrida. However, the more important question is not one of norm, truth, or totalizationpart of all discourses and practices-but how they further or resist the interest of a particular class. On which side of history do you struggle? Marx maintains that the question of whether objective truth can be attributed to human thinking is not a question of theory but a practical question-hence, we must prove the truth of 
our own thinking in practice. A pedagogy of critique is a mode of social knowing that inquires into what is not said, into the silences and the suppressed or the missing, in order to un-conceal operations of economic and political power underlying the concrete details and representations of our lives. It reveals how the abstract logic of the exploitation of the division of labor informs all the practices of culture and society. Materialist critique disrupts that which represents itself as natural and thus as inevitable and explains how it is materially produced. Critique, in other words, enables us to explain how social differences-gender, race, sexuality, and class-have been systematically produced and continue to operate within regimes of exploitation - namely within the international division of labor in global capitalism, so that we can fight to change them (Ebert \& Zavarzadeh, 2008).

Thus, a pedagogy of critique is about the production of transformative knowledges. It is not about liberty as the freedom of desire, because this liberty, this freedom of desire, is acquired at the expense of the poverty of others. A pedagogy of critique, as Ebert (2009) points out, does not situate itself in the space of the self, or in the space of desire, or in the space of liberation, but in the site of collectivity, need, and emancipation. A pedagogy of critique is grounded not in desire, but revolutionary love, that is, recognizing that love can only exist between free and equal people who have the same ideals and commitment to serving the poor and the oppressed. It is this moral affinity that constitutes the conditions of possibility of love. A pedagogy of desire works against the creation of revolutionary love by celebrating the unknowable, the endless deferral of meaning and the impossibility of certainty (Ebert \& Zavarzadeh, 2008). The principle of uncertainty is one of the key framing mechanisms of capitalism and the expansion of the market. It is about creating new ways to access cheap labor by disturbing social conditions under capital's relentless expansion. In all sites of everyday life under capitalist social relations we have institutional power relations which are not free spaces that foster equality. Thus, we need a pedagogy of critique grounded in revolutionary love in the struggle for transforming these social relations.

\section{References}

Ebert, T. (2009). The task of cultural critique. Urbana: University of Illinois Press.

Ebert, T., \& Zavarzadeh, M. (2008). Class in culture. Boulder and London: Paradigm Press.

Fischer, E. (1996). How to read Karl Marx. New York: Monthly Review Press.

Foster, J. B. (1996). Introduction. In E. Fischer, How to read Karl Marx (pp. 730). New York: Monthly Review Press. 
Meszaros, I. (2008). The challenge and burden of historical time: Socialism in the twenty-first century. New York: Monthly Review Press.

Rikowski, G. (2007, September). Critical pedagogy and the constitution of capitalist society. Paper prepared for the "Migrating University: From Goldsmiths to Gatwick" Conference, Panel 2, "The Challenge of Critical Pedagogy." Goldsmiths College, University of London. Available at http://www.flowideas.co.uk/?page=articles\&sub=Critical\%20Pedagogy\% 20and\%20Capitalism

Robinson, W. (2008). Latin America and global capitalism: A critical globalization perspective. Baltimore: The Johns Hopkins University Press.

San Juan, E. (2002). Racism and cultural studies. Durham, North Carolina: Duke University Press.

Scatamburlo-D'Annibale, V. (2009). Imagining the impossible: Revolutionary critical pedagogy against the $21^{\text {st }}$-century American imperium. In Mustafa Eryaman (Ed.), Peter McLaren, education, and the struggle for liberation: Revolution as education (pp. 19-54). Cresskill, NJ: Hampton Press, Inc.

\begin{abstract}
Author
Peter McLaren is a professor of urban schooling in the Graduate School of Education and Information Studies at the University of California, Los Angeles. $\mathrm{He}$ is the author, co-author, editor, and co-editor of over forty books and monographs. Several hundreds of his articles, chapters, interviews, reviews, commentaries, and columns have appeared in dozens of scholarly journals and professional magazines.
\end{abstract}

